UDC: 336

JEL: G210

L.W.Ollows ${ }^{1}$, A.Moro ${ }^{2}$, F.Mugo-Waweru ${ }^{1}$

\title{
BENEFITS OF SMALL AND MEDIUM ENTERPRISE LENDING FOR COMMERCIAL BANKS IN KENYA
}

\author{
${ }^{1}$ Strathmore University, P. O. Box 5985700200 Nairobi, Kenya \\ ${ }^{2}$ Cranfield University, School of Management, Building 111 Cranfield, Bedfordshire, MK43 0AL, UK
}

A review of research on bank financing reveals that there are mutual benefits to be gained by both borrowers and lenders when they engage in small and medium enterprise (SME) lending. However, most studies emphasize the demand side, or the borrower, benefits and largely ignore lender benefits. Therefore, with the increased commercial banks' interest in the SME sector, it is important to determine the supply side, or the lender, benefits if lenders are to continue serving these firms. The main objective of this study is to determine the benefits that commercial banks gain when they finance small and medium enterprises. Data is collected through semi structured interviews, conducted with SME bank managers who work closely with SMEs, and analyzed using content analysis. The study yields fourteen benefits that commercial banks in Kenya enjoy from engaging in SME lending.

Keywords: small and medium enterprise lending, benefits of small and medium enterprise lending, commercial banks, Kenya.

\section{ПРЕИМУЩЕСТВА КРЕДИТОВАНИЯ МАЛОГО И СРЕДНЕГО БИЗНЕСА ДЛЯ КОММЕРЧЕСКИХ БАНКОВ КЕНИИ}

\author{
Л. В. Оллоуз ${ }^{1}$, А. Моро ${ }^{2}$ Ф. Муго-Ваверу ${ }^{1}$ \\ ${ }^{1}$ Стратморский университет, Р. О. Вох 59857 00200, Найроби, Кения \\ ${ }^{2}$ Крэнфилдский университет, Школа менеджмента, стр. 111, Крэнфилд, Бердфордшир, \\ MK43 0AL, Великобритания
}

Обзор исследований в области банковского финансирования показывает, что кредитование фирм малого и среднего бизнеса выгодно как заемщикам, так и кредиторам. Однако большинство работ фокусируется на тех выгодах, которые получает сторона спроса, т.е. заемщик, при этом в значительной степени игнорируются выгоды кредитора. Поскольку интерес коммерческих банков к кредитованию фирм малого и среднего бизнеса растет, важно установить также выгоды стороны предложения, т.е. кредиторов, если они планируют обслуживать эти фирмы в дальнейшем. Основная цель настоящего исследования - определить выгоды, которые получают коммерческие банки при финансировании фирм малого и среднего бизнеса. Данные были собраны в ходе полуструктурированных интервью с менеджерами банков, тесно сотрудничающих с малым и средним бизнесом, и анализировались с помощью контент-анализа. В результате проведенного исследования выявлено четырнадцать преимуществ, которые получают коммерческие банки Кении, кредитуя фирмы малого и среднего бизнеса.

Ключевые слова: кредитование малого и среднего бизнеса, преимущества кредитования малого и среднего бизнеса, коммерческие банки, Кения.

() Санкт-Петербургский государственный университет, 2018 


\section{INTRODUCTION}

Small and medium enterprise (SME) financing has been a topic of keen interest in research because of the key role that SMEs play in economic development and their potentially important contribution to economic diversification and employment [Beck, Demirguc-Kunt, Levine, 2005; Ayyagari, Beck, Demirguc-Kunt, 2007; UNECE, 2007]. In Sub-Saharan Africa, banks have an important role to play due to their dominance in the financial systems and the limitations of informal finance, especially in regard to serving the higher end of the SME market [Ayyagari, Demirgüç-Kunt, Maksimovic, 2012]. SMEs depend on these financial institutions for their external financing needs because their small size and lack of substantial public information about their quality prevent them from accessing public capital markets such as through the issuance of commercial paper, bonds, or publicly traded equity [Beck et al., 2008; Holod, Peek, 2013; Santikian, 2014].

Compared to other Sub-Saharan and low income countries, Kenya is a developing country with a financial system that sees higher deposits in financial institutions and higher levels of credit channeled to the private sector [Beck, Fuchs, 2004]. Most of the businesses in Kenya are SMEs and these provide most of the employment opportunities [Katua, 2014]. Consequently, the highest contributor to GDP in Kenya is the SME sector. There is widespread agreement among financial sector stakeholders that the small business sector is at the heart of a vibrant private sector and as such increasing access to financial services for SMEs is a key pillar of the Comprehensive Financial Sector Reform and Development Strategy [Kenya Treasury, 2011].

G. Berg and M. Fuchs [Berg, Fuchs, 2013] find that bank competition in the SME market segment is strongest in Kenya compared to most Sub-Saharan African countries with all banks interested in developing their engagement with SMEs regardless of size (small, medium or large) or ownership (domestic or foreign). According to a study by Financial Sector Deepening (FSD) [FSD Kenya, 2015], SME finance has continued to increase gradually both in absolute terms and relative to the banks' total lending portfolio. In 2009, it represented 19,5 per cent of the total portfolio, in 2011 it was 20,9 per cent, and 23,4 per cent in 2013. Between 2009 and 2013, SME lending by foreign banks increased in absolute terms but decreased relative to domestic banks, confirming a growing role played by local players in the SME market. In an earlier study, Berg and Fuchs [Berg, Fuchs, 2013] attributed this trend to innovation in Kenya, compared to other Sub-Saharan African countries, that started through a combination of microfinance-rooted institutions scaling up to become commercial banks and innovation with lending models and technology in the retail banking segment by other institutions.

The Kenyan economy was expected to grow by 6-7\% in 2015-2017 [FSD Kenya, 2015]. Given the pivotal role SMEs play in fueling innovation and employment-creation, understanding the opportunities, gaps and challenges in the SME finance market is crucial to maintaining the current growth momentum. The financial sector's role to channel 
credit affordably and efficiently to these enterprises is therefore very central for inclusive and sustained economic development [FSD Kenya, 2015].

In order to determine whether SME lending is viable in future, it is important to understand the benefits to both parties involved; the lender and the borrowers. Studies suggest that there are mutual benefits to be gained, however most studies focus on the benefits that accrue to the borrower; largely ignoring the commercial banks who take the initiative to invest in SME lending (see: [Petersen, Rajan, 1994; 1995; Berger, Udell, 1995; Cole, 1998; Elsas, Krahnen, 1998; Harhoff, Körting, 1998; Bharath et al., 2007]).

With the increased interest in the SME sector by commercial banks, it is important to determine supply side or lender benefits if lenders are to continue serving these firms. The main objective of this study is therefore to determine the benefits that commercial banks gain when they finance SMEs.

\section{LITERATURE REVIEW}

In their survey of 91 banks in 45 countries, Beck et al. [Beck, Demirguc-Kunt, Martinez Peria, 2011] find that banks perceive the SME segment as highly profitable. Similarly, P. Calice et al. [Calice, Chando, Sekioua, 2012] study the extent of bank lending to SMEs in Kenya, Uganda, Tanzania and Zambia and find that banks perceive the SME segment as large, unsaturated, with good prospects and strategically important. Like A. De la Torre et al. [De la Torre, Martinez Pería, Schmukler, 2010] who use data from bank surveys for a total of 48 banks (plus one leasing company) in 12 countries, Calice et al. [Calice, Chando, Sekioua, 2012] also find that the common drivers of bank involvement with SMEs are, perceived profitability, reduction of information asymmetry and reverse factoring.

Perceived profitability is cited as a major driver of bank involvement with the SME segment [Calice, Chando, Sekioua, 2012; De la Torre, Martinez Pería, Schmukler, 2010] which concurs with the earlier findings of S. Bharath et al. [Bharath et al., 2007]. Calice et al. [Calice, Chando, Sekioua, 2012] find that 63 per cent of the banks they interviewed (in Kenya, Uganda, Tanzania, and Zambia) expect high profits from working with SMEs. In Kenya, specifically, 50 per cent of banks were motivated to participate in the SME market in view of its profitability. De la Torre et al. [De la Torre, Martinez Pería, Schmukler, 2010] find that a majority of banks consider that the SME segment's profitability will more than compensate for the higher costs and risks of the segment. Furthermore, De la Torre et al. [De la Torre, Martinez Pería, Schmukler, 2010] find that many banks perceive the SME segment to be more profitable than corporate banking. They explain this by the fact that spreads on corporate lending are near zero (due to high competition) and as such banks are looking for new markets to diversify their income sources. The perceived profitability of working with SMEs not only derives from lending products, but also from the potential for cross-selling other products. Once a bank has established a relationship with the borrowing SME, the bank may offer a variety of 
other services and obtain revenues from the fees they charge for these services [De la Torre, Martinez Pería, Schmukler, 2010]. This coincides with the later findings of Holod and Peek [Holod, Peek, 2013] that banks may profit from relatively inexpensive core deposits placed with the bank by their relationship borrowers in addition to the earlier findings of A. Boot [Boot, 2000] that rate-insensitive core deposits allow for intertemporal smoothing in lending rates. This suggests a complementarity between deposit taking and lending. More recently, A. Fredriksson and A. Moro [Fredriksson, Moro, 2014] analyze 4285 firm-year observations from Finnish banks and find that the length and scope of a relationship, and the loan dimensions, are important in explaining the risk-adjusted profitability of banks.

The development of lender-borrower relationships should also reduce information asymmetry especially where borrowers are considered information opaque as in the case of SMEs [Holod, Peek, 2013]. This perceived benefit concurs with the basic premise of the theories of financial intermediation [Leland, Pyle, 1977; Diamond, 1984; 1991; Ramakrishnan, Thakor, 1984; Fama, 1985; McNulty, 2002]. Boot [Boot, 2000] suggests that relationship banking can facilitate a Pareto-improving exchange of information between the bank and the borrower, where a borrower might be inclined to reveal more information than in a transaction-oriented interaction and the lender might have stronger incentives to invest in producing information. The continuous contact between borrower and lender in the provision of various financial services can produce valuable information which the lender can use in making decisions. These decisions include; whether to extend credit or not, how to price loans, whether to require collateral and whether to attach other conditions to the loan [Elyasiani, Goldberg, 2004]. M. Puri, J. Rocholl, and S. Steffen [Puri, Rocholl, Steffen, 2010] concur and find that relationships provide value to banks in the screening process of loan applications by retail customers as well as in the monitoring process even after the improvement in the initial screening process. This agrees with the earlier studies of Boot [Boot, 2000] and R. Rajan [Rajan, 1996]. Boot [Boot, 2000] concludes that relationship lending can pave the way for more informative credit contracting decisions based on a better exchange of information and also increase the availability of credit to information-sensitive borrowers. Rajan [Rajan, 1996] suggests that the benefits of a relationship may include the transfer of proprietary information, a commitment to continue doing business together through financially tough times, or the offer and delivery of services at prices different from costs.

On the contrary, E. Von Thadden [Von Thadden, 1992] suggests that even though a relationship may lead to one bank having a monopoly of information over other banks, this would be unfavourable for the borrower. In an earlier study, Boot [Boot, 2000] highlights this monopoly problem when he proposes that relationships are the primary cause of an incumbent bank's comparative advantage over new lenders. J. Garriga [Garriga, 2006] refers to this as the "dark side" of relationship lending where one bank may end up having a monopoly of information over other lenders and thus be able to extract more interest income from borrowers. E. Lehmann and D. Neuberger 
[Lehmann, Neuberger, 2001] as well as G. Hernandez-Cánovas and P. Martinez-Solano [Hernandez-Cánovas, Martinez-Solano, 2006] confirm this when they find evidence of this higher cost of credit. Holod and Peek [Holod, Peek, 2013] explain that this higher cost of credit though higher than is justified by the level of credit risk perceived by an informed lender, is lower than the interest rate that would be charged by other potential lenders to the firm due to the higher risk premium required to compensate them for the added risk associated with being less informed about the firm. Thus, the firm does not have an incentive to defect from the relationship and begin a new relationship with another lender because it is costly and time consuming to establish new lending relationships. Therefore, firms are subject to a "lock-in" effect with their current relationship lender [Holod, Peek, 2013]. This concurs with the earlier findings of C. Howorth, M. Peel, and N. Wilson [Howorth, Peel, Wilson, 2003] that firms will only be informationally captured when the costs of switching banks, including the costs of conveying an accurate picture of their performance to prospective bankers, outweigh the benefits.

S. Greenbaum, G. Kanatas, and I.Venezia [Greenbaum, Kanatas, Venezia, 1989], Rajan [Rajan, 1992], and S. Sharpe [Sharpe, 1990] provide another explanation for the higher cost of credit charged by banks who have established a relationship when they predict that interest rates increase as the relationship lengthens because lenders subsidize the borrowers initially but are reimbursed with higher rates later. Bharath et al. [Bharath et al., 2007] find contrasting evidence that lenders do not extract monopoly rents through higher interest rates and fees (spreads) on loans to their relationship borrowers. Similarly, M.Petersen and R. Rajan [Petersen, Rajan, 1994] find higher credit costs related to firms' simultaneous multiple bank relationships in contrast to the view that this higher cost of credit occurs when a bank has a monopoly of information, or is the main/sole bank.

Bharath et al. [Bharath et al., 2007] find that a lender that has a strong relationship with a borrower is able to lend more and has a greater probability of providing future loans compared to a lender lacking such a relationship. Many bankers view the generation of additional business as the principal reason for engaging in relationship lending. Holod and Peek [Holod, Peek, 2013] concur and add that additional sources of value for the relationship lender would arise through the opportunities for cross selling additional products and services to its relationship borrowers. Such value would reflect not only the profitability from current business with the firm, but the profits that might accrue to the bank from future opportunities to continue and expand the menu of products and services provided to the firm as the firm expands, both in terms of size and activities. L. Santikian [Santikian, 2014] in a study of the small business loan portfolio of a midsized bank in the United States, finds that the source of value in relationships in banking is not limited to enhanced monitoring but relationships also enable banks to sell borrowers a variety of other profitable financial services, as well as gain access to additional borrowers to whom they can sell these services. These findings are similar to Bharath et al. [Bharath et al., 2007] and Holod and Peek [Holod, Peek, 2013]. 
Holod and Peek [Holod, Peek, 2013] provide direct evidence on the value of relationship lending to banks. By using data from a small business loan survey in the U.S., they find that small commercial and industrial loans do, in fact, add value for smaller banking organizations, both in absolute terms and relative to the value contributed by larger commercial and industrial loans. Interestingly, the value-enhancing effect emanates primarily from the smallest loans, those with original values of $\$ 100,000$ or less. On the other hand, small commercial real estate loans, being transactional rather than relationship in nature, do not contribute additional value to banking organizations relative to larger commercial real estate loans [Holod, Peek, 2013].

The need to seek out SME relationships from existing large corporate clients (reverse factoring) is also cited as another driver of bank involvement in the SME segment. This is reported by almost 70 per cent of the banks in Argentina and 25 per cent of the banks in Chile [De la Torre Martinez Pería, Schmukler, 2010]; and 50 per cent of banks in Kenya [Calice, Chando, Sekioua, 2012]. Banks systematically ask large clients for references on their best clients and suppliers which in many cases are SMEs. With a list of potential clients, banks contact these companies and try to on board them by offering services or lending products, depending on the banks' strategy. The benefit banks reap from this is not only that banks obtain an assessment of the quality of these SMEs from large clients, but also that these SMEs are supported by operating with these large corporations, who in some cases also provide guarantees [Elyasiani, Goldberg, 2004]. J. McNulty [McNulty, 2002] concurs and adds that these banks are also able to monitor borrowers and diversify their risk by contracting with a large number of borrowers. Thus, banks gain very useful information and reduce the risk of seeking new clients and in this way, exploit the synergies of working with different types of clients.

More recently, Fredriksson and Moro [Fredriksson, Moro, 2014] state that one of the major shortcomings of previous research on bank profitability is that it tends to look for the determinants of the overall profitability, whereas overall profitability depends on the profitability that a bank can extract from its financial relationship with each individual customer. After analyzing 4285 firm-year observations from Finnish banks, authors find that the major factor in explaining the risk-adjusted profitability of banks is the quality of a SME's performance although the length and scope of a relationship and the loan dimensions also play an important role [Fredriksson, Moro, 2014].

The empirical studies above resulted in perceived or potential benefits that lenders could enjoy by engaging in SME lending. Boot [Boot, 2000] concludes that there is still much more work required to determine the precise sources of value of SME lending, because existing work falls short in measuring the precise sources of the added value of relationship banking (see: [Boot, 2000]). This conclusion is also later echoed by Calice et al. [Calice, Chando, Sekioua, 2012] when they point out that relatively little research exists on whether and why banks finance SMEs around the world. What emerges from the empirical studies above is that SME lending is carried out (see: [Calice, Chando, Sekioua, 2012; De la Torre, Martinez Pería, Schmukler, 2010]), which implies that the 
question on whether SME lending is carried out, has been answered. This study seeks to then determine what benefits commercial banks gain by engaging in SME lending in an attempt to answer the question "why" banks finance SMEs.

\section{METHODOLOGY}

A qualitative multiple case study design is adopted for this study. A qualitative research approach is found suitable for this study as the research question seeks to determine "what" and "how" as opposed to a quantitative study that asks "why" and looks for a comparison of groups or relationships between variables, with the intent of establishing an association, relationship, or cause and effect [Creswell, 1994]. A qualitative inquiry also supports the researcher's aim of acquiring knowledge and understanding of the problem by using an inside perspective [Creswell, 2009]. Multiple case study design is considered suitable for this study because the researcher aims to explore the research problem in depth using one or more individuals. R. Yin [Yin, 2004] proposes that a case study design should be considered when the researcher has little control over events and the focus is on a contemporary phenomenon within a real-life context; as is the case for this study. Evidence from multiple cases adds "confidence" to the research findings and is often more compelling resulting in a more robust study [Miles, Huberman, 1994; Yin, 2004].

The seven commercial banks selected for this study are those that have been ranked top three, for the years 2010 to 2014, in the banking survey organised by Think Business Limited [Banking Survey, 2010; 2011; 2012; 2013; 2014]. Think Business Limited is a leading strategic business intelligence, research and publishing company in Kenya specializing in the financial sector [Banking Survey, 2013]. Data is collected through semi-structured interviews with sixteen SME relationship managers/branch managers from each bank (see interview guide in Appendix). This is in line with the minimum number of interviews recommended in literature for such a study (see: [Bertaux, 1981; De Ruyter, Scholl, 1998; Ritchie, Lewis, Elam, 2003]).

Content analysis is used to analyse the data following the three concurrent flows of activity suggested by M. Miles and A. Huberman [Miles, Huberman, 1994]: data reduction, data display, and conclusion verification. First, the researcher begun, by a deep reading of the text, followed by a search for similar words or phrases that were stated by the interviewees. Second, the similar words and phrases were put into categories/themes. The generation of themes was twofold; some themes had been identified a priori and the researcher sought evidence for participants' expressions relating to those themes, additionally the researcher also allowed new themes to emerge from the analysis of the transcripts. The third step in the analysis involved the assignment of codes representing the core topic of each category. The assignment of codes was followed by the fourth step which involved the reduction of data by condensing it into summaries/paraphrases. Finally, the resulting data was displayed in rich verbatim text in tables and from these tables; data was further analyzed to produce summaries that enabled conclusions to be drawn. 


\section{EMPIRICAL RESULTS}

The enquiry on the benefits of SME lending to commercial banks resulted in fourteen benefits that banks enjoy due to lending to SMEs. Respondents from each of the seven banks in the study indicated one or more benefits they enjoy from lending to SMEs as shown in the table.

Table. Benefits of SME lending to commercial banks

\begin{tabular}{|c|c|c|c|c|}
\hline Benefits & Respondents & $\begin{array}{l}\text { Number of } \\
\text { respondents }\end{array}$ & $\begin{array}{c}\text { Number of } \\
\text { banks }\end{array}$ & Rank \\
\hline 1. Banking the economy & B1a, B7a, B7c & 2 & 2 & 9 \\
\hline 2. Growth in the SME bank book & B1a, B2a, B6b & 3 & 3 & 6 \\
\hline 3. Cheap deposits & B1a, B2a, B7a & 3 & 3 & 7 \\
\hline 4. Higher interest & $\begin{array}{l}\text { B1a, B1c, B2a, B4a, B5b, } \\
\text { B6c, B7a, B7b, B7c }\end{array}$ & 8 & 6 & 1 \\
\hline $\begin{array}{l}\text { 5. Reputation building and a } \\
\text { stronger brand } \\
\end{array}$ & B1b, B5b, B6a & 3 & 3 & 5 \\
\hline $\begin{array}{l}\text { 6. Government recognition and } \\
\text { support }\end{array}$ & B5b & 1 & 1 & 14 \\
\hline 7. Non-funded income & B1a, B1c, B2a, B5b, B6b, B6c & 4 & 4 & 4 \\
\hline 8. Successional business growth & B1a & 1 & 1 & 13 \\
\hline 9. Income tentacles & $\begin{array}{l}\text { B1a, B1b, B2a, B3a, B3b, } \\
\text { B6c, B7a }\end{array}$ & 7 & 5 & 3 \\
\hline $\begin{array}{l}\text { 10. Innovation of products/ } \\
\text { competitive advantage }\end{array}$ & B2a, B6b, B7c & 3 & 3 & 8 \\
\hline 11. Source of foreign exchange & B2a, B6c & 2 & 2 & 10 \\
\hline 12. Relationship & B6b & 1 & 1 & 12 \\
\hline 13. Less competition & B7a & 1 & 1 & 11 \\
\hline 14. Profitability & $\begin{array}{l}\text { B1c, B3a, B3b, B5c, B6a, } \\
\text { B6c, B7a, B7b }\end{array}$ & 8 & 5 & 2 \\
\hline 15. Not yet reaped any & B5a & 1 & 1 & \\
\hline
\end{tabular}

N o t e s: B1, B2, up to B7 refer to Bank One, Bank Two up to Bank Seven. Key: a - the first respondent; $\mathrm{b}-$ the second respondent; $\mathrm{c}$ - the third respondent.

Each of the above benefits is discussed below.

1. Banking the economy. B1a states that banking SMEs implies banking almost all businesses in the economy as SMEs form 80 per cent of the businesses. B7a agrees and explains that SMEs allow banks to penetrate all sectors of the economy, an aspect that is not present when banks concentrate only on the big corporates. SME banking enables the bank meet its target in terms of what they refer in a soft way as corporate social responsibility, as this is one of the sectors that the bank strategically tries to support (B6c). B7a concludes that as SMEs are driving the economy, that is where money is circulating. 
2. Growth in the SME bank book. As the SME market is huge and untapped it has potential for growth (B2a) concurring with B1a's assertion that there is value in banking SMEs as they grow the bank's SME book.B6b adds that being relational helps retain customers as opposed to being just a transactional.

3. Cheap deposits. SMEs are a source of cheap deposits to the banks as compared to deposits placed by large corporates. This is because the amount deposited by any one SME customer is not that large compared to corporate deposits and as such SMEs are not able to negotiate for high deposit rates (B1a, B2a, and B7a).Banks are therefore able to save on SME deposits.

4. Higher interest. B1c highlights that the higher the risk as is the case with SMEs the higher the return and as such banks that bank SMEs have an opportunity to price higher. B4a finds that as SMEs need the money, they take loans more seriously than the bigger corporates (scared of implications) unlike a corporate who will know the bank will take 90 days before they send an auctioneer. The lack of bargaining power by SMEs due to the small amounts of deposits placed means that SMEs are also unable to negotiate for lower rates on lending and as B6c puts it, SMEs are very simple and all they want is to get a loan and fast, are easy to convince (B7b) and will rarely sit down to negotiate with a bank that does accommodates them (B7c). B2a agrees when they emphasize that the SME market is not sensitive to pricing as their deposits are not huge and therefore do not have bargaining power but they do need loans. Corporate are able to negotiate for lower lending rates (B4a) and concessions (B2a) due to the huge deposits they place at banks and to some extent banks' hands are tied because competition for the big corporates is so high. The interest margins for corporates are much, much slimmer than SMEs and as such banking SMEs allows banks to enjoy higher interest margins as SMEs of course have the best margins because of demand (B7a). As such interest income is a prevalent benefit for banks that lend to SMEs (B1a, B2a, B4a, B5b, B6c, B7a, B7b, and B7c).

5. Reputation building and a stronger brand. According to B5b, banks can also build a reputation and a stronger brand through dealing with SMEs. B6a agrees and explains that capacitating SMEs to grow translates to easier monitoring of these enterprises which translates to lower risk and costs, and eventually more revenue for the bank. B1b summarizes that SMEs market for the banks, as the brand sells itself.

6. Government recognition and support. Banks that support SMEs also get government recognition and support as these banks are contributing to the economic growth of the country, of the nation (B5b). B5b gives the example of such recognition and support by government; invitation to conferences and meetings to discuss SMEs lending. Further, the government may also choose to disburse funds targeted to the SMEs through these banks resulting again in cheap deposits for the bank and additionally, earnings on commissions and ledger fees.

7. Non-funded income. Bank lending to SMEs also results in additional income that arises from transactions (transactional income) for instance, RTGS (Real Time Gross Settlement), cheque book processing, TT (Telegraphic Transfer) amongst others, 
which banks refer to as non-funded income (B1a, B1c). B2a explains that non-funded income is any income not generated from lending which includes commissions from other services offered and adds examples of these; bid/performance bonds, transactional income from normal operations of account-withdrawals and cash handling fees (small but many transactions). These also include commissions and ledger fees (B5b). As SMEs do a lot of trading, banks are able to make some money through collection of nonfunded income (B6c). Trading may also see these SMEs deal in foreign currency and thus are a source of foreign exchange for the bank (B2a, B6c). B2a adds that this is an untapped market that is huge/big and has potential for growth.

8. Successional business growth. B1a adds that banks also benefit through successional business growth, growing with SMEs to corporate implies that banks continue to enjoy their retail income.

9. Income tentacles. According to B1a, SMEs have income tentacles, which $\mathrm{B} 2 \mathrm{a}$ agrees to and refers to as a "pipeline" and B3a, B3b call a "penetration strategy". Apart from non-funded income, SMEs open up avenues to additional sources of income for the bank. These income tentacles include; banking SME employees without necessarily incurring costs marketing for it (B1a, B1b, and B7a). Whereas banking big corporates limits the bank's penetration to only a few sectors e.g. agriculture and pharmaceuticals, SME banking enables banks penetrate to all sectors of the economy e.g. technology, media and manufacturing. This occurs through referrals, for instance if a customer is in the transport business he can have 5 other referrals who deal in different aspects of transport for instance, logistics (B1b) and referrals to other SMEs who are suppliers or clients of the SME client (B2a). B3a and B3b further state that SMEs may offer leads to a big corporate, just like a big corporate may offer leads to a SME and conclude that it is important to finance SMEs to meet needs of distribution as SMEs are a lever, because they are interdependent on so many other existing and potential clients. B6c agrees and adds that since the environment we operate in is based on value chains, and most SMEs will probably be the primary mover in their independent value chain, a bank that ignores this sector is setting itself up for failure (B6c).

10. Innovation of products/competitive advantage. $\mathrm{B} 2 \mathrm{a}$ and $\mathrm{B} 7 \mathrm{c}$ add that another benefit of banking SMEs is that they are a source of ideas and out of the relationship, drive bank innovation of products which B6b agrees and adds that this may lead to the bank having a competitive advantage. Further, B2a states that when such a product is rolled out, it can be tested with the same SMEs before rolling it out for all SMEs. Related to product innovation, B6b mentions that one source of value they are getting from their customers is the relationship as they recognise that this leads to fulfilment of a customer need in future which may lead to an innovation and ultimately give the bank a competitive advantage to serve them more.

11. Source of foreign exchange. B2a indicates that SMEs are a source of foreign exchange for those that deal in foreign currency; this is an untapped market that is huge/ big and has potential for growth. A similar benefit is stated by B6c that SMEs do a lot of trading, importing things and trading FX (foreign exchange) and the bank makes some 
money there on the exchange which is a huge opportunity and unfortunately not many banks have taken time to understand SMEs.

12. Relationship. B6b states that they get a relationship form their customers because such a focus "ensures continued business with these customers... you see that is our key focus in relationships because you see banking is changing and now we are focusing more on other items apart from just getting income from the customer... the rest of course will just come in handy... you know when you relate with your customers you tend to keep them longer in your bank as opposed to when the relationship is just transactional".

13. Less competition. According to B7a, another benefit from banking SMEs is that competition for them may not be as high as for corporates. Corporates are fewer and may have restrictions as to where they can bank for instance in the case of multinationals. B7a refers to the SME market as an open playing field.

14. Profitability. Respondents were found shy to state that the end result of banking SMEs is the profits they make. Those that out rightly state it include B1c that states that with SMEs there is an opportunity for the bank to be able to intermediate profitably, while B3a and B3b refer to SMEs as levers that enable them make profits. The only value $\mathrm{B} 5 \mathrm{C}$ indicates is profitability. $\mathrm{B} 6 \mathrm{C}$ states that it is the most profitable sector for the bank which is echoed by B7a and B7b. However, B6a qualified that it is important to remember that banks are only profitable to the extent their customers are profitable.

15. Not yet reaped any. The respondent $\mathrm{B} 5 \mathrm{a}$ indicated the bank had not yet reaped any benefits from SME lending.

\section{DISCUSSION}

The data collected on SME lending benefits yields about fourteen benefits that banks enjoy due to lending to SMEs. Respondents from each of the seven banks in the study indicated one or more benefits they enjoy from lending to SMEs. Interestingly, one respondent, $\mathrm{B} 5 \mathrm{a}$, indicates that their bank has not yet started reaping the benefits of SME lending which is in disagreement with other respondents from the same bank who detail benefits they are already enjoying. The most prevalent is higher interest which is indicated by eight respondents from six banks and this benefit is closely followed in popularity by profitability indicated by eight respondents from five banks. It can be argued that higher interest may lead to higher profits and as such these two benefits may be related. The least popular benefits, as these were indicated by only one respondent in each case, are; government recognition and support, successional business growth, relationship and less competition. Again some, if not most, of the benefits may be interlinked and directly or indirectly translate to value for the bank in terms of increased profitability. The immediate and direct benefit of SME lending is that it adds to the SME book. Lending to an additional SME may then indirectly lead to three benefits; interest income perhaps from higher priced loans due to the higher risk, cheap deposits (due to lack of bargaining power by SMEs since deposit amounts are small relative to corporate 
deposits) and non-funded income arising from transactions. The three benefits may translate to greater profitability for the bank.

Alternatively, growing the SME book by adding an SME customer may indirectly result in several income tentacles; for instance; referral to a firm (both SME or big corporate) in the SME's value chain or referral to other SMEs or banking of the SME employees. These income tentacles may market the reputation or brand of the bank or form part of the corporate social responsibility strategy for the bank. However, the converse may also occur such that the reputation, brand and CSR activities of the bank result in the income tentacles. As a result, the income tentacles also lead to interest income, cheap deposits and non-funded income arising from transactions which may translate to greater profitability for the bank.

The indirect benefit of income tentacles may imply that a bank gets to support more SMEs and banks that support SMEs may get government recognition and support as these banks are contributing to the economic growth of the country. Also, the reputation or brand and CSR activities of the bank may lead to such recognition by the government. An example of such recognition and support by government is invitation to conferences and meetings to discuss SMEs lending. Banks may benefit if the government chooses to

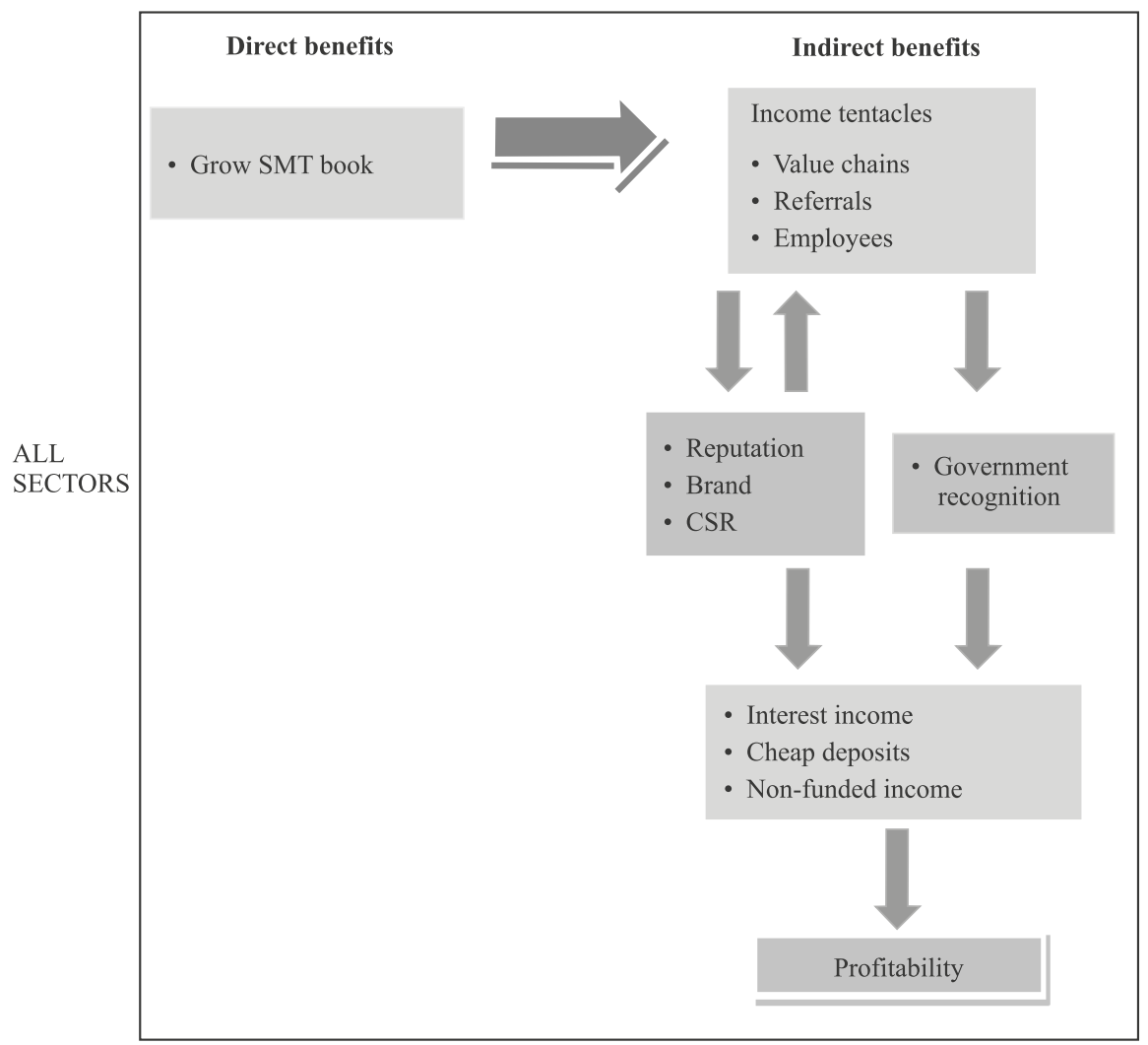

Figure. Direct and indirect benefits of SME lending to commercial banks 
disburse funds targeted to the SMEs through them, resulting again in cheap deposits for the bank and non-funded income which translates to greater profitability.

A diagrammatic representation of these benefits and their interconnectedness is presented in the figure below.

\section{CONCLUSION}

As previous studies that focus on the benefits of SME lending to lenders tend to provide only indirect evidence about the value-enhancing effects of lending relationships on the banks [Holod, Peek, 2013], this study establishes the actual benefits being enjoyed by banks engaged in SME lending. Further the study shows that these benefits are interlinked and directly or indirectly translate to value for the bank in increased profitability. The benefits determined in this study confirm the perceived benefits in prior studies and add to the existing knowledge on the benefits of SME lending to commercial banks. With these actual benefits it may be possible to predict the viability and scale of relationship banking in the future as suggested by Boot [Boot, 2000].

Limitations of the study. The first limitation relates to the generalisability of qualitative studies and more specifically, the case study design. The common criticisms of case studies are that one cannot generalise from a single case and a single case does not add to scientific development. As the nature of the study is qualitative, it does not claim to be generalizable and is based on specific epistemological foundations that have a way of contributing knowledge [Adelman, Jenkins, Kemmis, 1980]. The knowledge generated by this study is thus significant in its own right. However being that it was a multiple case study there was the possibility to generalise through the cross case analysis [Miles, Huberman, 1994].

Secondly, four interviewees were reluctant to have the interview recorded. As these respondents had already expressed their willingness to participate in the study, in these cases, the researcher requested to take notes during the interview process and all the respondents agreed. To further allay their concerns about confidentiality of the information, the researcher assured them that the reporting of the results would be such that it would not be possible to identify the bank. Further they would be given an opportunity to validate the interview by confirming that what was represented in the interview transcript was what was discussed and where they had an opportunity to amend the transcript; including and removing any data.

Third, this study was carried out in banks that operate only in Kenya and as such can only be applicable to other countries or financial markets after due consideration of the differences in financial and regulatory environment. However the basis of this research was to gain knowledge and not to generalise to other contexts.

Implications of the study. Researchers interested in the area of SME lending will find this study useful as it has added to the existing body of knowledge on SME lending by exploring the supply side or lender's perspective in commercial banks in Kenya (a developing country in sub Saharan Africa) and has also made a methodological contribution 
by using a qualitative approach in the study of SME lending methods employed and benefits to commercial banks.

For commercial banks interested or already involved in SME lending this study has provided information on benefits that can accrue due to SME lending. This information will enable banks make decisions on whether and how to continue contracting with the SME segment; as such whether SME financing is viable for them in future.

\section{References}

Adelman C., Jenkins D., Kemmis S. 1980. Re-thinking case study: Notes from the second Cambridge Conference. In: H.Simons (ed.). Towards a Science of the Singular: Essays about Case Study in Educational Research and Evaluation. Norwich [Norfolk]: Centre for Applied Research in Education, University of East Anglia; 47-61.

Ayyagari M., Beck T., Demirguc-Kunt A. 2007. Small and medium enterprises across the globe. Small Business Economics 29 (4): 415-434.

Ayyagari M., Demirgüç-Kunt A., Maksimovic V.2012. Financing of Firms in Developing Countries Lessons from Research. World Bank Policy Research Working Paper N 6036.

Banking Survey. 2010. The Best Banks in Kenya. Nairobi, Kenya: Think Business Ltd.

Banking Survey. 2011. The Best Banks this Decade 2001-2010. Overall Rankings. Think Business Ltd., Nairobi, Kenya.

Banking Survey. 2012. Kenya: Think Business Ltd., Nairobi, Kenya.

Banking Survey. 2013. Kenya: Think Business Ltd., Nairobi, Kenya.

Banking Survey. 2014. Kenya: Think Business Ltd., Nairobi, Kenya.

Beck T., Demirgüç-Kunt A., Levine R. 2005. SMEs, growth, and poverty: Cross-Country evidence. Journal of Economic Growth 10 (3): 199-229.

Beck T., Demirgüç-Kunt A., Maksimovic V. 2008. Financing Patterns around the World: Are Small Firms Different? Journal of Financial Economics, 89 (3): 467-487.

Beck T., Demirguc-Kunt A., Martinez Peria M. 2011. Bank financing for SMEs: evidence across countries and bank ownership types. Journal of Financial Services Research 39 (1-2): 35-54.

Beck T., Fuchs M. J. 2004. Structural Issues in the Kenyan Financial System: Improving Competition and Access. World Bank Policy Research Working Paper N 3363. URL: http://ssrn.com/ abstract $=610406$ (accessed: 22.05.2015).

Berg G., Fuchs M.2013. Bank Financing of SMEs in Five Sub-Saharan African Countries: The Role of Competition, Innovation, and the Government. Policy Research Working Paper N WPS 6563. Washington, DC: World Bank. URL: http://documents.worldbank.org/curated/ en/2013/08/18091735/bank-financing-smes-five-sub-saharan-african-countries-rolecompetition-innovation-government (accessed 10.04.2015).

Berger A. N., Udell G. F. 1995. Relationship lending and lines of credit in small firm finance. Journal of Business 68 (3): 351-381.

Bertaux D. 1981. From the life-history approach to the transformation of sociological practice. In: D. Bertaux (ed.), Biography and Society: The Life History Approach in the Social Sciences. Beverly Hills, Calif.: Sage Publications; 29-45.

Bharath S., Dahiyab S., Saunders A., Srinivasan A. 2007. So what do I get? The bank's view of lending relationships. Journal of Financial Economics 85 (2): 368-419.

Boot A. W. A. 2000. Relationship banking: What do we know? Journal of Financial Intermediation 9 (1): 7-25.

Calice P., Chando V., Sekioua S. 2012. Bank Financing to Small and Medium Enterprises in East Africa: Findings of a Survey in Kenya, Uganda, Tanzania and Zambia. African Development Bank. 
Cole R. 1998. The importance of relationships to the availability of credit. Journal of Banking and Finance 22 (6-8): 959-977.

Creswell J. W. 1994. Research Design: Qualitative and Quantitative Approaches. Thousand Oaks, CA: Sage Publications.

Creswell J. W. 2009. Research Design: Qualitative, Quantitative, and Mixed Methods Approaches. 3rd ed. Thousand Oaks, CA: Sage Publications.

De la Torre A., Martinez Pería M.S., Schmukler S. L. 2010. Bank involvement with SMEs: Beyond relationship lending. Journal of Banking \& Finance 34 (9): 2280-2293.

De Ruyter K., Scholl N. 1998. Positioning qualitative market research: Reflections from theory and practice. Qualitative Market Research: An International Journal 1 (1): 7-14.

Diamond D. W. 1984. Financial intermediation and delegated monitoring. Review of Economic Studies 51 (3): 393-414.

Diamond D. W. 1991. Monitoring and reputation: The choice between bank loans and directly placed debt. Journal of Political Economy 99 (4): 688-721.

Elsas R., Krahnen J. P. 1998. Is relationship lending special? Evidence from credit file data in Germany. Journal of Banking \& Finance 22 (10-11): 1283-1316.

Elyasiani E., Goldberg L. 2004. Relationship lending: A survey of the literature. Journal of Economics and Business 56 (4): 315-330.

Fama E. F. 1985. What's different about banks? Journal of Monetary Economics 15 (1): 29-39.

Fredriksson A., Moro A. 2014. Bank-SMEs relationships and banks' risk-adjusted profitability. Journal of Banking \& Finance 41 (4): 67-77.

FSD Kenya. 2015. FinAccess Business - Supply: Bank Financing of SMEs in Kenya.

Garriga J.M. 2006. Relationship Lending and Small Business Finance: Empirical Analysis of Cost of Capital, Credit Rationing, and Firm Performance. Economics and Business Department, Universitat Pompeu Fabra, Barcelona.

Greenbaum S.I., Kanatas G., Venezia I. 1989. Equilibrium loan pricing under the bank-client relationship. Journal of Banking and Finance 13 (2): 221-235.

Harhoff D., Körting T. 1998. Lending relationships in Germany: Empirical results from survey data. Journal of Banking and Finance 22 (10-11): 1317-1354.

Hernandez-Cánovas G., Martinez-Solano P. 2006. Banking relationships: Effects on debt terms for small Spanish firms. Journal of Small Business Management 44 (3): 315-333.

Holod D., Peek J. 2013. The Value to Banks of Small Business Lending. Federal Reserve Bank of Boston Working Paper N 13-7.

Howorth C., Peel M. J., Wilson N. 2003. An examination of the factors associated with bank switching in the U. K. small firm sector. Small Business Economics 20 (4): 305-317.

Katua T. N. 2014. The role of SMEs in employment creation and economic growth in selected countries. International Journal of Education and Research 2 (12): 461-472.

Kenya Treasury. 2011. Kenya: A Comprehensive Financial Sector Reform and Development Straegy.

Lehmann E., Neuberger D. 2001. Do lending relationships matter? Evidence from bank survey data in Germany. Journal of Economic Behaviour and Organization 45 (4): 339-359.

Leland H., Pyle H. 1977. Informational asymmetries, financial structure, and financial intermediation. Journal of Finance 32 (2): 371-387.

McNulty J.E. 2002. Finance theory, lender liability, and the value of banking relationships: A survey and interpretation. Quarterly Journal of Business and Economics 41 (3/4): 83-95.

Miles M.B., Huberman A.M. 1994. Qualitative Data Analysis: An Expanded Sourcebook. 2nd ed. Thousand Oaks, CA: Sage.

Petersen M. A., Rajan R. G. 1994. The benefits of lending relationships: Evidence from small business data. The Journal of Finance 49 (1): 3-37.

Petersen M.A., Rajan R.G. 1995. The effect of credit market competition on lending relationships. Quarterly Journal of Economics 110 (2): 407-443. 
Puri M., Rocholl J., Steffen S. 2010. On the importance of prior relationships in bank loans to retail customers. SSRN Electronic Journal 10/2011. DOI: 10.2139/ssrn.1572673.

Rajan R. 1992. Insiders and outsiders: The choice between informed and arm's length debt. Journal of Finance 47 (4): 1367-1400.

Rajan R. 1996. Why banks have a future: Toward a new theory of commercial banking. Journal of Applied Corporate Finance 9 (2): 114-128.

Ramakrishnan S., Thakor A. V. 1984. Information reliability and a theory of financial intermediation. Review of Economic Studies 51 (3): 415-432.

Ritchie J., Lewis J., Elam G. 2003. Designing and selecting samples. In: J.Ritchie, J.Lewis (eds.). Qualitative Research Practice. A Guide for Social Science Students and Researchers. Thousand Oaks, CA: Sage; 77-108.

Santikian L. 2014. The ties that bind: Bank relationships and small business lending. Journal of Financial Intermediation 23 (2): 177-213.

Sharpe S. A. 1990. Asymmetric information, bank lending and implicit contracts: A stylized model of customer relationships. Journal of Finance 45 (4): 1069-1087.

UN/ECE Secretariat. 2007. SMEs - Their role in foreign trade. URL: www.unece.org http://www. unece.org/contact/UNECE404.htm (accessed: 12.01.2015).

Von Thadden E.L. 1992. The Commitment of Finance Duplicated Monitoring, and the Investment Horizon. WWZ Discussion Paper N 9207.

Yin R. K. 2004. Case study methods. In: J.L.Green, G.Camilli, P.B.Elmore (eds.) Handbook of Complementary Methods in Education Research. American Educational Research Association, Lawrence Erlbaum Associates, Inc.; 111-122. URL: http://www.centralbank.go.ke/ financialsystem/banks/Register.aspx (accessed: 07.02.2012).

For citation: Ollows L. W., Moro A., Mugo-Waweru F. Benefits of Small and Medium Enterprise Lending for Commercial Banks in Kenya. Vestnik of Saint Petersburg University. Management, 2018, vol. 17, issue 2, pp. 168-184. https://doi.org/10.21638/11701/spbu08.2018.202

Contact information

Lilian W. Ollows _ PhD, Lecturer; lollows@strathmore.edu

Andrea Moro - PhD, Reader in Finance; andrea.moro@cranfield.ac.uk

Freshia Mugo-Waweru - PhD, Senior Lecturer; fwaweru@strathmore.edu 


\section{INTERVIEW GUIDE FOR THE SME RELATIONSHIP/LOAN MANAGER}

1. Introduction

a) Purpose of the research - to establish the benefits of small and medium enterprise (SME) lending to commercial banks in Kenya.

b) Research will be confidential, with tape recorder for analysis purpose only, and will be undertaken by the doctoral researcher.

2. Respondent background
a) Job title.
b) Length of service.
c) Responsibilities.

3. Technical/functional aspects
a) How does your bank define a SME?
b) For how long has your bank been engaging with SMEs?

4. SME Lending

Kindly elucidate why your bank engages in SME lending.

5. Value/Benefits

What is the value or benefit that the bank generates from lending to SMEs?

Thank you very much for your time and participation in this study. 